\title{
The Constitution of the European Union
}

Dennis C. Mueller

University of Vienna

\begin{abstract}
.
In this paper I take a critical look at the draft constitution of the EU. I focus on six aspects of the constitution: (1) the way in which it was written, (2) the goals of the European Union as set forth in the constitution (3) citizenship in the EU as defined by the constitution (4) whether the EU should be designed as a confederation, a federation, or some hybrid, and the answers to these questions given by the constitution, (5) how the work of government should be divided between the EU and the member states, and what the constitution has to say on this question, and (6) rights as they are defined in the Charter of Fundamental Rights, which is part of the proposed constitution. I conclude that the EU would be better off rejecting the proposed constitution and drafting a new one.
\end{abstract}

A constitution is one of, if not the most - important political institutions in a country. It defines the rules within which the political game of the country will be played, establishes for whom the game is being played by defining citizenship, defines the rights of the citizens, and creates the institutions through which these rights will be protected. Up until now the constitution of the European Union has been a series of treaties among the member countries dating back to the EU's founding almost a half century ago. As such, it is rather cumbersome and difficult to understand, and has certainly failed to achieve the kind of common sense of political identity among Europeans that, say, the US Constitution has achieved among Americans.

With this in mind the decision was made a few years ago to draft a new constitution for the European Union. This draft now exists and is currently going through a ratification process in the member countries. In this paper I take a critical look at the draft constitution and the way that it was written, and suggest that in the long run 
the EU would be better off rejecting this constitution and drafting a new one. The proposed constitution is long and complicated. No effort will be made to examine every article in detail. Instead, I select specific parts that I believe are particularly problematic, and make my case for rejecting the constitution by discussing these.

I begin by criticizing the way in which the constitution was written (Section I). Section II is concerned with the goals of the European Union as set forth in the constitution. Section III takes up the question of citizenship in the EU. In Section IV I discuss the issue of whether the EU should be designed as a confederation, a federation or some hybrid, and the answers to these questions given by the constitution.

Section $\mathrm{V}$ goes on to discuss the issue of how the work of government should be divided between the EU and the member states, and what the constitution has to say on this question. Section VI is concerned with rights as they are defined in the Charter of Fundamental Rights, which is part of the proposed constitution. My conclusions are drawn in Section VII.

\section{The Nature of a Constituton}

There are two ways of thinking about a constitution. One sees it as a kind of social contract among the citizens creating the state, and derives its intellectual pedigree from the work of contractarians like Hobbes, Locke and more recently Buchanan and Tullock (1962) and Rawls (1971). The other way to think about a constitution is simply as a blueprint for how the state operates. The constitution defines the rules of the game so that those who play the game - the politicians and bureaucrats working within the state - know how to play it.

The contractarian literature has given rise to a branch of public choice that falls under the heading of "constitutional political economy." Under the constitutional political economy approach, citizens are assumed to write the constitution, which creates the state, with the goal of advancing their collective interests. The constitution is a contract 
among the citizens creating the state. In writing this contract the citizens confront a principal-agent problem. How to write a constitution that will constrain those in office to advance the interests of the citizens and not their own interests. Although no constitution has literally been written and signed by all citizens, a logical implication of the first approach would naturally be that the citizens should elect representatives to a special convention that would draft a constitution.

This, of course, was not the way the European Union constitution was written. It was drafted by a special convention established to write the constitution, but the delegates to this convention were selected by the political elite of Europe. The result is a constitution of the second type discussed above - a constitution written by the political elite for the political elilte, a constitution that describes in great detail how the institutions of the EU will operate in the future. Had the constitution been written by the citizens or at least for the citizens, one would expect it to be a reasonably short document that most citizens could easily read and understand. Instead, it is a document of create length and complexity, a source of reference for those working in the state.

\section{The Goals of the European Union}

The European Union was established with the primary goal of joining France and Germany and the other founding countries so closely together both economically and politically that they would never go to war with one another again. Subsequently, the goal of establishing a common market was added. In achieving these goals the EU must be regarded as a great success.

Part 1 of Article $\mathrm{I}-3$ of the constitution captures these goals admirably and succinctly.

1. "The Union's aim is to promote peace, its values and the well-being of its peoples." 
Although the expression "its values" is a little vague, they have in fact been defined in the previous article. If the statement of goals had stopped here, one could only applaud. But it does not stop here. Part 3 of Article I-3 states:

3. "The Union shall work for a ... social market economy, highly competitive and aiming at full employment ..."

What pray tell is a social market economy? Even more objectionable, however, is the last part of the quote. Now the word "aiming" is a kind of weasel word, which does not necessarily imply that the EU will reach full employment, or even come very close to achieving it. All it really says is that we would like to achieve full employment. But even as such it is objectionable, since there are no institutions created by the constitution for achieving this goal. The institution that arguably has the greatest impact on unemployment is the European Central Bank. But its mandate is price stability, and its zealous pursuit of this goal since its founding has arguably led to greater unemployment rather the less.

The article goes on to list other goals - "social progress, scientific and technological advance, protections of children's rights, social and territorial cohesion"to name only some. If a poor person in a new member country who feels worse off following entry into the EU were to ask what is in it for her, do we really want to say, social progress and technological advance? Is a primary goal of the European Union really to achieve territorial cohesion, whatever that may be?

Of course, protecting children and achieving full employment are admirable achievements, and one might simply say that it does not hurt to list them, even if the EU is not designed to achieve them. I do not think that their inclusion in the constitution as goals of the European Union comes without cost, however, for they represent the kinds of platitudes politicians glibly utter during election campaigns, but fail to deliver on when in office. Should an EU citizen ever read the constitution and its long list of platitudinous 
goals, she might develop the same cynicism about the promises included in the constitution that many citizens hold about the promises of political parties.

\section{Citizenship in the European Union}

Article 1-8 creates a new class of citizenship.

1. "Every national of a Member State shall be a citizen of the Union. Citizenship of the Union shall be additional to national citizenship; it shall not replace it."

Most citizens of member states, if asked today if they are citizens of the EU, would probably answer yes, reasoning that citizenship in a member country bestows upon them citizenship in the EU and allows them to take up residence and work in other EU countries, etc. Why then create a new additional category of EU citizenship?

There are two possible answers to this question. The first is that this article is merely symbolic. By creating a largely redundant category of EU citizenship, the drafters of the constitution wanted to symbolize that yet another step toward "an ever closer union" had been taken. Alternatively, the article is meant to have real teeth. The constitution includes the Charter of Fundamental Rights (discussed below). This Charter has a long list of rights, many of which are economic rights that potentially obligate the state to spend money to fulfill them. The courts in the United States have interpreted US citizenship as implying that a person moving from one state to another fairly soon has full entitlement to the welfare benefits provided by the new state of residence. If the European Court of Justice would interpret European citizenship as US courts have interpreted American citizenship, citizens of poor countries could move to rich ones and quickly qualify for the more generous welfare benefits of the richer countries. Such a development would quickly spell the end of the welfare states of Europe, as they have existed until now.

When one thinks of the rights of citizenship, one immediately thinks of the right to vote. If EU citizenship allows me to live and work in any member state, should it not 
also allow me to vote in any member state's elections after I take up residency there. Presumably, this occurred to the drafters of the constitution and so they included a provision allowing one to vote in municipal elections in the country of residence? Why municipal but not also national? Cynically, I expect that some members of the convention said, "oh no, we cannot have people coming from other countries and voting in our national elections, they might change the outcomes." Someone else then said, "but EU citizenship should include the right to vote where one lives." "OK," said the first person, "let them vote in municipal elections, nothing very important gets decided at the municipal level in EU countries. ${ }^{\text {,ii }}$

\section{The Political Structure of the European Union}

When thinking about the optimal design of the European Union, the key question to answer is whether the EU should be structured as a federation or a confederation.iii A confederate structure is optimal, if one can assume that all citizens within a country have the same preferences for the policies to be decided at the EU level, and that these differ from one country to another. When this is the case, all citizens in a country can be effectively represented by a member of the elected government, and the proper seat of legislative power in the EU should be the Council.

Alternatively, one might argue that preferences are heterogeneous within countries. People favoring strong environmental protection, people favoring tough controls over asylum seekers, and so on, can be found in every country. If this is the case, a federate structure is optimal with citizens represented by parties that compete for votes across the entire EU, and the proper seat of legislative power is the European Parliament.

A third possibility would be that for some EU decisions the first assumption about preferences is most appropriate, for others the second assumption. In this case 
maintaining both the Council and the Parliament would be optimal with one group of decisions assigned to the Council, the rest to the Parliament.

The occasion of writing a new constitution for Europe was a perfect opportunity to address this question and determine what the EU should be. The draft constitution failed to take up this challenge. It by and large maintains the status quo with both the Council and Parliament sharing decision making power in many areas. This outcome could have been predicted as soon as the composition of the convention was determined. It included representatives from the Commission, from the Parliament, and from the governments of the member countries. If a radical restructuring of EU decision-making institutions had been required to represent EU citizens optimally, the convention as constituted could never have agreed to such a restructuring for it would have meant significantly reducing the decision-making powers of one of the constituent groups at the convention. The fact that all of the major players under the current EU structure were well-represented in the convention ensured that the current structure would be maintained. Indeed, the only players not well-represented in the convention were the citizens.

\section{The Assignment Problem}

In a political entity of the size of the European Union the work of the state must be subdivided among different levels of government. The main criteria for deciding which level of government should be responsible for which governmental activities are the extent of spillovers from a government activity and the degree of homogeneity of

preferences of the citizens within a jurisdiction. ${ }^{i v}$ The second criterion plus their history as independent states dictate that a large fraction of public goods and services be provided by the member states, regardless of whether the EU were organized as a federation or a confederation. The occasion of writing a new constitution presents a 
perfect opportunity to clarify exactly what the division of responsibilities will be. Article I9, entitled Fundamental Principles, addresses the issue.

1. "Under the principle of subsidiarity in areas which do not fall within its exclusive competence the Union shall act only if and insofar as the objectives of the intended action cannot be sufficiently achieved by the Member States, either at a central level or at a regional and local level, but can rather, by reason of the scale or effects of the proposed action, be better achieved at Union level."

As a general (fundamental) principle it is admirable. But who decides whether a given competence should lie with the member states or the Union? It would appear that this competence lies with Brussels. Should a member state disagree, it can challenge Brussels in which case the European Court of Justice must decide. Since its founding an ever expanding list of competencies has been claimed by Brussels. Will the Court choose to protect the sovereignty of the member states against the desires of those in Brussels, or will it share with Brussels the view that "an ever closer union" of the member states requires an ever expanding scope of authority at the central level?

A major tenet in the public finance/choice literature on federalism is that responsibility for redistribution should lie with the central government (Oates, 1972). The reasoning behind this recommendation is that if redistribution takes place and the regional or local levels, poor people will migrate to the locations with the most generous redistribution policies, thereby bankrupting these levels of government. This need not happen within the EU, however, if redistribution remains at the member state level, since the member states can restrict their redistribution programs to their own citizens. Their ability to do so is called into question, however, by Article I-8 creating European Union citizenship for all citizens of member countries. Will the European Court of Justice allow member states to continue to discriminate against citizens from other member states as far as redistribution programs are concerned, or will it use Article I-8 to prohibit such discrimination? The constitution leaves the door open to the kind of 
destructive migration when redistribution is not centralized, which public finance/choice economists have warned against.

\section{Rights in the European Union}

Article 1-7 makes the Charter of Fundamental Rights a part of the constitution. This Charter, like the constitution itself, was written a few years ago by a special convention formed by delegates from each member country. These delegates, like those to the constitutional convention, were chosen by the political elites in the respective countries. I would guess that only a very small minority of citizens in each country was even aware that a Charter of Rights was being written. I would guess that even a smaller minority in each country has read the Charter. Before discussing the Charter, I need to sketch out my theory of constitytional rights, which I shall then use to critique some of the rights defined by the Charter. ${ }^{v}$

\section{A. The Nature of Constitutional Rights}

Imagine a group of people sitting down to write a constitution that creates institutions to make future collective decisions. Each person is uncertain about exactly what decisions will come up in the future, and about what her preferences will be on these issues. On the other hand, people can envisage in a general way the types of collective decisions that will arise, and can be expected to group certain sorts of issues together and use a particular voting rule to decide them.

All collective decisions can be treated as dealing with actions. An ideal constitution will allow people the freedom to do or not to do whatever they want - unless the action carries with it a negative externality. The constitution writers will wish to grant the future collective decision-making body the authority to pass laws to curb negative externalities. 
Let $m$ be the majority required to decide an issue, $0<m \leq 1$. An $m=0.5$, or 0.5 plus one vote is the simple majority rule; $m=0.667$ is the two-thirds majority rule, and so on. It is easy to show for any action involving a negative externality that the $m^{*}$ that maximizes the expected utility or welfare of someone at the constitutional stage depends on the utility loss to the person prevented from acting relative to the utility loss imposed on others from the action. The larger is the utility loss to the person prevented from acting relative to the utility loss imposed on others, the higher is the optimal $m^{*}$ for preventing the action. For any $m<0.5$ it is possible for mutually inconsistent issues to pass. For example, with $m=0.4$ a proposal to increase spending on education might get 42 percent of the vote and pass, and a proposal to decrease spending passes with 43 percent of the vote. To avoid such inconsistencies the constitution writers would no doubt limit consideration to voting rules for which $0.5<m \leq 1$.

For many types of collective decisions - banning trash burning, imposing speed limits - the lower bound for the range of $m$, that is to say the simple majority rule, will be optimal. For some actions, however, the loss to a person prevented from acting will be so large relative to any possible negative externalities that the action might cause that the constitution writers will wish to allow the community to ban the action only in the event that such a ban achieves a super majority, as say $2 / 3$ rds. And conceivably for some actions, the loss to an individual prevented from acting will be so large relative to any possible negative externalities that the constitution writers will allow a ban of the action only in the event that such a ban achieves the unanimous support of the community.

An example of such an action might be practicing one's religion. Some religions require that their members wear certain clothes, not cut their hair or beards, or other actions that irritate other members of the community. Bans on such religious practices have been common. If the loss to persons prohibited from practicing their religion is perceived by those writing the constitution to be very great relative to any possible 
externalities these actions cause, the constitution writers would require that any bans of religious practices receive unanimous support.

One might wonder how it could ever come about that a ban of a religious practice could obtain unanimous support, for this would mean that members of the religious group voted to ban their religious practice. A religious group might go along with such a ban, however, if it were offered something in compensation.

Although this might happen, if the constitution writers have correctly identified religion as needing the protection of the unanimity rule, it is unlikely that the community will offer a large enough bribe to reach consensus. A long debate over the ban takes place, and in the end some members of the religious group vote against it and it is defeated.

At the time that they write the constitution, its drafters can look forward and envisage many proposals to ban certain religious practices, because they create negative externalities for some members of the community. They can foresee lengthy debates over the bans and in the end the community is unable to convince all members of the religious group to vote for the ban and the proposal fails. Recognizing this, the constitution framers may choose to protect religions not by requiring unanimity to impose a ban, but by defining a constitutional right to practice one's religion.

Definition. A constitutional right guarantees an individual's freedom to undertake an action, or to refrain from the action, without interference from any other members of the community either acting separately or collectively through the state.

A constitutional right guarantees an individual's freedom to undertake an action, but does not compel it. Thus, the same outcomes are possible with a constitutional right as with the unanimity rule. If the rest of the community chooses to offer a sufficiently large bribe, they can persuade the religious group not to exercise its right. If religious practices have been correctly identified for rights protection, however, such 
occurrences are likely to be rare, since the great asymmetries in gains and losses from the action will preclude the community's offering a large enough bribe.

Constitutional rights have the advantage over the unanimity rule in protecting certain actions in that they avoid the lengthy debates that would surround proposals to ban the actions. Under my theory, constitutional rights are low transaction cost substitutes for the unanimity rule. There are three properties of constitutional rights as defined by this theory that are worth emphasizing.

1. Constitutional rights need to be defined explicitly only in situations in which a negative externality from an action is perceived to be strong enough that it might happen in the future that someone proposes banning the action. No matter how much pleasure people get out of scratching their ears, there is no need to define a right to scratch one's ear explicitly in the constitution, if one cannot imagine anyone proposing a ban on ear scratching.

2. There is an inherent tension between constitutional rights and the principle of majoritarian democracy that many people associate with democracy. Constitutional rights will be defined precisely in those situations in which the constitution writers do not want to allow a simple majority of the community the possibility of banning an action.

3. Unlike many people's conceptions of rights, constitutional rights are inherently relative. They depend on the constitution writers' conceptions of the benefits to individuals from undertaking certain actions and the losses these actions will impose on others, and these are likely to differ across communities or within a community over time with respect to at least some actions.

To illustrate the last point, consider a right found in many constitutions - some form of habeas corpus protection. We can all agree that the costs imposed on someone who is imprisoned are likely to be great. This alone does not justify a right to go free, if one has not been charged and convicted of a specific crime, however. To justify such a right it must also be the case that any externalities associated with 
allowing the person to go free are relatively small. This might be the case in Italy and Austria where such rights exist. Imagine, however, that the people living in Israel were to write a constitution for a single country. Even if both Jews and Arabs were able to slip behind a veil of ignorance and imagine being a member of the other religious group - admittedly a big if - they might not agree on placing an article dealing with habeas corpus protection in the constitution. The history of violence in that country has been such that both groups might judge the external costs of allowing members of some groups to go free at some points in time to be so large that they would want to allow the state to lock members of these groups up for certain periods of time. The kind of habeas corpus protection that may be optimal in Italy and Austria may not be optimal in Israel or Northern Ireland.

\section{B. Rights in the Charter}

There are two questions to address concerning rights in the European Union. Should there be rights at both the Union level and the member state level? If so, should Union level rights be allowed to "trump" member state rights, laws and constitutional provisions?

Constitutional rights at the member state level can be defended if people are immobile across countries and have heterogeneous preferences across countries. Under these assumptions the people in one country may perceive different benefits and external effects from an action and wish to define different constitutional rights.

Constitutional rights at the Union level can be defended if people are highly mobile across countries. I live in Austria today, but tomorrow I or my children may live in Portugal or Poland and I want the same rights protection whereever I or they may choose to live. Alternatively, one could defend rights at the Union level if people step behind a veil of ignorance and imagine being someone in a different country. I live in Austria today, and never expect to leave it. Nevertheless, I identify with people in 
Portugal, Poland and the other EU countries and I want them to have the same rights protection as I have. I desire a common set of rights for all EU citizens, and thus favor EU level rights with the power to trump national policies, to ensure that no nation can take an action that would remove one of these rights.

Let us now take a look at some of the rights defined in the Charter. Some of the definitions are so vague that it is difficult to know whether the asymmetry condition for defining a right is met or not. Article 35, for example, ensures "a high level of human health protection." Now if by high level of human health protection is meant an operation to save a life, it might accord with our theory of rights. The gain to the person getting the operation is great and the loss to the rest of the community from paying for the operation is presumably relatively small. But one might interpret "high level" much more broadly - the best that money can buy, or the best that money buys in the richest EU country. If citizens in the poorest EU countries go to court and demand health protection on a par with the richest countries does Article 35 give them that right? If not, exactly what right does it give?

Articles 37 and 38 ensure high levels of environmental and consumer protection. Does someone who receives only a medium level of environmental or heath protection suffer a great loss relative to receiving a high level? If not, a right is not justified. How does one measure the height of consumer protection?

Articles 33 offers the family "social protection." What precisely does than mean?

Some of the articles are redundant or contradictory. Article 21, for example, states that, "Any discrimination based on any ground such as sex ... 16 additional criteria ... shall be prohibited." The first sentence of Article 23 goes on to ensure "equality between men and women." Such equality would, one would think, already have been ensured by the prohibition against discrimination on the grounds of sex contained in Article 21. Remarkably and contradictorily, the second sentence in Article 
23 explicitly allows for discrimination on the grounds of sex, when it leads to "specific advantages in favour of the under-represented sex."

Some articles merely offer commentary or advice. The second provision under Article 12, for example, informs us that "Political parties at Union level contribute to expressing the political will of the citizens of the Union." A profound observation without doubt, but in what sense does it define a "fundamental right"?

While many of the articles of the Charter are ambiguous or cannot be defended by as rights, others are quite clear in their meaning. A few of these, however, raise the risk of conflict between the EU and member countries. Article 2, for example, explicitly forbids capital punishment and thus would, presumably, preclude any country's introducing capital punishment for any type of crime, however serious. If there is one thing one can learn from the painful history of capital punishment in the United States it is that opinions over its efficacy can vary greatly over time and across a large polity at a particular point in time. With 25 members and counting can one really say that no EU country will ever choose to introduce capital punishment? Recent assassinations in the Netherlands have led some of its citizens to call for the introduction of capital punishment for certain crimes. If the Netherlands were to take this step, should the other EU countries vote it out of the EU? Would this make the EU a better place?

Article 5 prohibits slavery and forced labor and would, under a liberal interpretation, make conscription for military and civil service unconstitutional. Articles 11 and 12 ensuring freedoms of expression and association would, under a liberal interpretation, make Germany's and Austria's laws regarding the Nazi Party unconstitutional.

Enough has probably been said to convince the reader that many of the articles of the Charter are problematic. The inclusion of the Charter of Fundamental Rights in the constitution raises two dangers. First, many of the rights proclaimed in the Charter, like offering families "social protection," will prove to be unenforceable in the courts. 
Instead of the constitution becoming a contract among the citizens of Europe bestowing meaningful rights and liberties on all citizens, it becomes a vacuous list of the kinds of platitudes that politicians utter during elections, but fail to deliver in office - full employment, social protection of families, consumer protection, and so on.

The second danger is that some articles of the constitution, which threaten to overturn national laws and programs, will be enforced, and will produce bitter conflicts between member states and the European Union and its Court of Justice, thereby undermining the European Union's support in its member countries.

To avoid these twin dangers I recommend that the definition of rights be left to the individual member states as supplemented by the European Convention for the Protection of Human Rights, which all member states have already accepted. The Convention contains a much shorter list of rights than the Charter and, importantly, explicitly defers to the member states of such matters as conscription and the interpretation of free speech. It is far less likely to precipitate conflicts between Brussels and the member states.

\section{Conclusions}

The act of drafting a new constitution presented a golden opportunity to involve all European citizens in the constitutional evolution of the European Union, to decide whether the Union should be a federation or a confederation, to specify the responsibilities of the member states and of the Union and, as was claimed as a reason for holding a constitutional convention, to close "the democratic deficit in the EU." These goals might have been accomplished by holding elections in each member country to elect representatives to the convention. Candidates could have stated their views as to what the Union should be and how it should be organized, and citizens could have elected persons whose views they shared. Citizens would have been brought into the constitution writing process at the outset, and might then have taken a 
greater interest in the deliberations in the constitutional convention. An EU wide debate over the constitution might have been set off.

This, of course, was not the way that the constitution got written. Like all other steps in the EU's evolution, it has been elite driven. The political elite chose the delegates to the convention from among their own, and they proceeded to write a constitution that represents their views of what the European Union should be. In many countries like Austria, citizens will not even be given the opportunity to pass judgment on the final document. The position that ratification of the constitution is too important of a decision to be left to the citizens I find difficult to reconcile with the notion that the European Union is - or ought to be - a democracy.

At the time of this writing, polls in some countries, which are holding referenda like France, predict a rejection of the constitution by the citizens. Interviews suggest that many voters will vote against the constitution not so much because they are unhappy with the constitution per se, but because they are unhappy with their current government or do not trust its leaders (Bennhold and Dempsey, 2005). This seemingly irrational reason for voting no is in fact quite understandable. Since the citizens have not been involved in the constitution's drafting, their support or opposition to it is not based on how closely it comes to their ideal constitution. The length and complexity of the constitution has insured that very few citizens even bother to read it. Since the constitution has been written by the political elite, it is rational to assume that it reflects their ideals. If the citizen does not trust members of the political elite advocating a yes vote, why should she believe that such a vote will advance her interests? Deciding to vote yes or no based on a citizen's trust in the political elite in her country is a perfectly rational thing to do.

My recommendation is that the current draft of the constitution be rejected by the citizens of those countries, which have chosen to hold referenda. Many claim that if this happens the Union will be thrown into a "crisis." I do not see why this should be the 
case. A rejection would certainly be a great disappointment for those who wrote the constitution, and for those who see it as the next great step toward "an ever closer union," but I do not see why it would have a big impact on the lives of EU citizens, whose interests are presumably to be served by the constitution. If it is rejected, we shall simply continue to muddle along as we have under the existing constitutional structure as established by the previous treaties. Decisions will be made. Perhaps these will not be the same decisions that would have been made under the new constitution, but it is not obvious that they will be worse decisions than under the new constitution.

A rejection of the new constitution by the citizens of some of its member countries would, hopefully, lead members of the political elite to ask why the constitution was rejected. It might bring them to the conclusion that the constitution should serve the interests of the Union's citizens, and that they are in the best position to say what these interests are. Once the initial disappointment over a rejection passed, perhaps the political elite would start again to write a constitution, but this time doing so in such a way that it involved the citizens. 
Endnotes 


\section{References}

Alesina, Albert and Roberto Perotti. 2004. "The European Union: A Politically Incorrect View," Journal of Economic Perspectives, 18, Fall, pp. 27-48.

Alesina, Alberto and Enrice Spolaore. 2003. The Size of Nations. Cambridge, MA: MIT Press.

Bennhold, Katrin and Judy Dempsey. 2005. "Chirac's EU Push Sways Few Voters," International Herald Tribune, April 16-17, p. 1.

Blankart, Charles B. and Dennis C. Mueller, eds. 2004. A Constitution for the European Union, Cambridge, MA: The MIT Press (CESifo Seminar Series).

Buchanan, James M. and Gordon Tullock. 1962. The Calculus of Consent, Ann Arbor: University of Michigan Press.

Mueller, Dennis C. 1991. "Constitutional Rights," Journal of Law, Economics, and Organization, 7, September, pp. 313-33.

Mueller, Dennis C. 1996. Constitutional Democracy, Oxford/New York: Oxford University Press.

Mueller, Dennis C. 2004a. "Rights and Citizenship in the European Union," in Ch. Blankart and D.C. Mueller, eds., A Constitution for Europe, Cambridge, MA: MIT Press, pp. 61-84.

Mueller, Dennis C. 2004b. "Why Federalism?" in Per Molander (ed.), Fiscal Federalism in Unitary States, Dordrecht: Kluwer, pp. 131-44.

Oates, Wallace E. 1972. Fiscal Federalism, London: Harcourt Brace.

Rawls, John A. 1971. A Theory of Justice, Cambridge, MA: Belknap Press.

i For additional critical discussions and suggestions, see the essays in Blankart and Mueller (2004), and Alesina and Perotti (2004).

ii This is not true of all European countries. In Switzerland, many important decisions are made at lower levels of government. Switzerland has a strong federalist structure, however, something that is lacking in most EU countries.

iii For further discussion of this point, see Mueller (2004a).

iv See, Alesina and Spolaore (2003), and Mueller (2004b).

v For a fuller discussion, see Mueller (1991, 1996, Ch. 14). 